\title{
The state's responsibility towards entrepreneurs in the Czech Republic for the measures adopted in relation to the epidemic of coronavirus
}

\author{
Stanislav Bílek ${ }^{1, *}$, Zdeněk Caha ${ }^{1}$, and Vendula Velková $^{1}$ \\ ${ }^{1}$ Institute of Technology and Business in České Budějovice, Faculty of Corporate Strategy, Okružní \\ 517/10, 37001 České Budějovice, Czech Republic
}

\begin{abstract}
This paper briefly analyses the legislation of the state's liability for the measures adopted in relation to the epidemic of coronavirus in the period of the state of emergency, it especially deals with the state's liability for damage accrued upon entrepreneurs in a casual relation to the restriction of the right to engage in enterprise. The aim of the paper is to carry out a legal analysis of liability for damage according to the Crisis Act on one hand, and of liability for damage caused by the terminated measures of the state according to the Act referring to the protection of public health, on the other hand. The paper provides a practical guideline for claiming damages and draws attention to the limits of such claims.
\end{abstract}

Keywords: state of emergency, business, measures of general nature, liability for damage

\section{Introduction}

Shortly after the pandemic outbreak numerous studies that reflect the impact of the corona virus crisis from the medical, economic, social, environmental as well as legal points of view started to appear. Scientists started to quantify the impact of the ordered restrictions just after the pandemic outbreak. Firano and Fatine [1] model the economic consequences of the epidemic in Morocco in their research, and they emphasize that the choice of the restrictive policy has enabled reduction of the negative medical impacts of the pandemic. A study by Donthu, Gustafsson [2] points out serious economic consequences in the global scale, which lead to dramatic changes in the behaviour of businesses as well as consumers. Farias and de Araujo [3] point out the influence of the pandemic on the global food supplies and consequent grow of consumer prices. A study by Malinovsky et al. [4] observes that Russian economy has been strongly negatively affected by the restrictions and worsened macroeconomic indicators are also expected in the future. In relation to individual industries Varelas and Apostolopoulos [5] for example analysed the strategic approaches to management among entities involved in tourism, which were focused on the mitigation of the economic impacts. Restrictions introduced to prevent the virus from spreading have changed the life style from the roots, which has also accented social inequality. Countries as well as individual regions

\footnotetext{
* Corresponding author: stanislav.bilek@mail.vstecb.cz
} 
and municipalities had to seek quick solutions how to reduce the social-economic impacts and had to rely on their own abilities to respond flexibly and adapt themselves to the situation that has arisen [7]. Another study [8] emphasizes that the COVID-19 pandemic has forced the society worldwide to resort to social distancing to slow down the spreading of the SARSCoV-2 virus. Aldaco et al. [8] deals with the environmental impacts shortly after the pandemic outbreak. Studies also exist that point out the fact that the negative economic impact of the Covid 19 virus spreading might have political consequences and give rise to the strengthening of extremist groups and opposition movements and escalate into armed conflicts [9]. A study by Neumeyer et al. [10] on the other hand points out that Covid 19 also represents a great challenge to entrepreneurs and also an opportunity towards a permanently sustainable and circular economy.

It is obvious that the situation that has arisen is completely unique, where unexpected economic and social impacts are among others influenced by targeted legislative interventions of the state in search for the prevention of the system overloading.

\section{Methods and data}

The author uses the method of data collection based on analysing the valid legislation, above all, the constitutional legislation, the resolutions of governments, measures of general nature, and analysing judgements, academic papers. In terms of proposed measures, they are based on author's private practice.

The government of the Czech Republic adopted a resolution to declare an state of emergency for the territory of the Czech Republic for the reason of endangering health in relation to proving the incidence of coronavirus /designated as SARS CoV-2/ on the territory of the Czech Republic for the period of 30 days on 12th March 2020. The resolution was published in the Collection of Laws No. 69/2020. The following, inter alia, results from the text: 'the government order pursuant to sec. 5 paragraph a) to e) and sec. 6 Act No. 240/2000 sb. [11], Crisis Management and the Amendments of Certain Statues (the Crisis Act), as amended, crisis measure for dealing with the developed crisis situation whose specific implementation will be determined by the separate resolution of the government.'

On 09.04.2020 the government, in resolution published in the Collection of Laws No. $156 / 2020$, extended the state of emergency till 30.04.2020, with the prior consent of the Chamber of Deputies. Further, the Chamber of Deputies extended the state of emergency till 17.05.2020.

In relation to the declaration of state of emergency, the government, individual ministries and regional bodies have adopted dozens of measures. The adopted measures resulted in a significant limitation of fundamental human rights formulated in the Charter of Fundamental Rights and Freedoms, inter alia, the significant limitation of the right to do business and economic activities, above all, in the connection to the limitation or ban on the retail sale of goods and services.

The purpose of the following legal interpretation is to focus on the state's liability for damage accrued upon an entrepreneur in casual relation to the measures adopted by the bodies of public authority in the period of state of emergency, and the reviewability of these measures by courts.

Two lines of legal defence are considered; first, the state's liability for damage amended directly in Act No. 240/2000 Sb. [11], Crisis Management and the Amendment of Certain Laws (the Crisis Act), second, the states liability for damage caused by unlawful decisions according to Act No. 82/1998 Sb. [12], Liability for damage caused in the exercise of official 
authority by a decision or maladministration. The chosen way of defence is based on the legal form of adopted measures and on the body of the state having adopted the measure. The author focuses on the adopted resolutions of the government and on the measures of the Ministry of Health, as they encroached upon the rights of entrepreneurs the most significantly.

The regime of both acts is different, as damage, according to the Crisis Act, can be compensated without the state's divergence from prescribed rules or standards (the prerequisite of liability for damage will be the mere existence of an adopted measure), on the contrary, when the state is liable to unlawful decisions, the state must revoke the measure on the grounds of its unlawfulness. During legal analysis, the general amendment of liability for harm, according to the Civil Code, cannot be omitted. It cannot be excluded that the injured parties will assert their claims according to both legislations concurrently.

In relation to this issue, it is necessary to mention, whether and to what extent the adopted measures are the subject of the control of judicial power, either within general administrative judiciary or constitutional judiciary.

\section{Results}

\subsection{The analysis of legislation}

\subsubsection{Liability for damage according to the Crisis Act}

Article 26 of the Charta of Fundamental Rights and Liberties, which forms the constitutional order of the Czech Republic, states that 'Everybody has the right to the free choice of her profession and the training for that profession, as well as the right to engage in enterprise and pursue other economic activity،.

The piece of constitutional legislation No. 110/1998 Sb. [13], Regarding the security of the Czech Republic, modifies the rules for the limitation of fundamental human rights. Regarding the institute of state of emergency, it provided in Article 5 as follows: 'The government may declare a state of emergency in the event of natural disasters, environmental or industrial accidents, incidents or other dangers which pose a significant threat to lives, health or property, or internal order and safety. The Government will immediately inform the Chamber of Deputies of the declaration of an state of emergency, who may cancel the declaration.' Article 6 of the same piece of legislation provides further rules for the declaration of state of emergency: State of emergency can only be declared upon reasons given for a specific time period and specific area. Concurrently with the declaration of state of emergency the government must specify which rights, established in in a separate piece of legislation, and to what extent, are restricted in compliance with the Charter of Fundamental Rights and Liberties, and which liabilities, and to what extent, are imposed. Details are determined by law. State of emergency can be declared for the period not exceeding 30 days. The given period can only be extended after an earlier consent of the Chamber of Deputies. The state of emergency ends by the expiration of the period that it has been declared for unless the government or the Chamber of Deputies decides to terminate it before the expiration of this period.'

The assumption of accuracy to declare state of emergency is, inter alia, the determination of the grounds for a declaration, temporality and the determination of territorial extent and validity. It is especially a constitutional piece of legislation that imposes on the government of the Czech Republic which specific rights determined in the Charter of Fundamental 
Human Rights and Liberties are restricted by such measure. It results from the text of the resolution to declare an state of emergency by the government that the list of the restricted rights is absent, although the constitutional piece of legislation requires to determine it 'concurrently' with the declaration of state of emergency.

The details of the state of emergency are determined by Act No. 240/2000 Sb. [11], Crisis Management and the Amendment of Certain Laws (the Crisis Act). Our interest is primarily concerned with the issue of damages caused by the casual relation to the adopted crisis measures. This law determines the applicability and powers of statutory bodies and territorial self-governing units, the rights and liabilities of artificial legal persons and natural persons during preparing for crisis situations which are not related to establishing the defence of the Czech Republic against external attack, the dealing with them and the protection of critical infrastructure and liability to the violation of these obligations. Before analysing the issue of the state's liability for damage, we must define the concepts of crisis management and crisis measures. Crisis management is defined in section 2 of the law as: 'the sum of operating activities of the bodies of crisis management concentrated on the analysis and assessment of security risks and the planning, organising implementing and controlling of activities conducted in relation to $1^{\text {st }}$ preparation for crisis situations and the solutions therein or $2^{\text {nd }}$ protection of critical infrastructure. Crisis measure is an organisational measure or technological measure for the solution of crisis situation and removing its consequences, including measures infringing the rights and liabilities of persons'. For the purpose of this paper, it is important to conclude that crisis measures are a sum of all measures adopted in relation to the state of emergency by various competent bodies of public authority. The form of crisis measures can be a resolution of the government, a piece of legislation, regulation, measure of general nature, administrative decisions, factual acts enforced by the bodies of public authority.

State compensations are determined in the Crisis Act in the following provisions, sections 35 to 37. The author focuses on damage accrued upon entrepreneurs in relation to the restriction of free movement of persons and the restriction or complete ban on retail sale of goods and services, therefore, our interest is in the provision of section 36, called the compensation of damage. According to the provisions of sections 5 and 6 of the Crisis Act it is possible: 'for the shortest time possible and to the minimum necessary extent, that natural persons and artificial legal persons have the right of ownership and the right to use and enjoy restricted, inter alia, in terms of assets, free movement and residence in the determined territory endangered or inflicted by crisis situation, and the restriction also applies to the right to do business which would threaten the implemented crisis measures or infringe or make impossible their implementation.'

Liability for damage resulting from the adopted crisis measures is determined by the law as follows: 'The state is liable to compensate damage accrued upon artificial legal persons and natural persons in a casual relation to crisis measures and exercises (section 39, subsection 4) conducted according to this law. The state can be relieved from liability only where it proves that the injured party caused damage by himself or herself. Monetary compensation is provided by the body of crisis management that ordered the crisis measure or exercise, during which or as a result of which the damage or harm was caused. The claim for damages with provided reasons is put forward by an artificial legal person or natural person in writing to the competent body of crisis management within 6 months from the moment it became known, not more than 5 years from the moment of the occurrence of damage, otherwise the right extinguishes. The body of crisis management is entitled, in the cases deserving special attention, to adjudicate a claim even after the expiration of term for application or without application, however, not longer than 5 years from the moment of the occurrence of damage. The compensation of damage is not provided for artificial legal 
persons and natural persons responsible for the origin of harmful event. The body of crisis management is entitled to require to cover the costs that were incurred as the compensation for damage from the originator of accident or other event resulting in a crisis situation that required the imposition of crisis measures.'

Apart from that, the law determines reimbursements for the restriction of ownership right, providing material means and duty to work and work assistance.

Especially these practical conclusions for an entrepreneur incurred with crisis measures can be deduced from the above quoted provisions:

The state's liability for damage incurred upon by crisis measures is objective, therefore, the claim arises regardless fault

The prerequisite of liability is not the unlawfulness or erroneousness of adopted crisis measure, but its correctness. Therefore, it is not appropriate to require the measure be revoked

Actual damage and a loss of profit are reimbursed (as for a loss of profit note the judicial decision of the Supreme Court (NS) sp.zn. 25 Cdo 3798/2007, sp.zn. 25 Cdo 1649/2007 and sp.zn. 25 Cdo 1422/2016)

Damage may not occur directly in a casual relation to the declaration of the state of emergency, but 'in relation to' the subsequent crisis measure adopted according to the law or in the summary

The subject-matter of reimbursement is both damage to property and other than proprietary loss

Damage must occur in a casual relation to a crisis measure, while the fulfilment of this condition is proved by the injured party. It may be assumed that this aspect will be the most problematic in court disputes. The subject-matter of reimbursement will only be so called objectively anticipated damage. In relation to this, it is not possible to make a simple direct proportion between an adopted measure to restrict retail sale and a loss of profit. The adopted measure is not necessarily the only cause of damage. It concerns the issue of pandemic itself, what its course was like, what other measures it required and whether their actual or possible consequence was a fall in demand for goods or services of an entrepreneur. Therefore, the calculated loss of profit can relate to the fall in demand from different causes, such as the fear of customers, ordered quarantine and other measures concerning health of customers. It concerns the possible situation, what the demand for goods would have been if the crisis measure had not been adopted, or had been adopted to a different extent, and the rise of infected individuals had been exponential. It is certainly relevant to suggest to courts considering casual relations so that they would assess the effects of the measures of neighbouring countries and their bodies, especially the closures of state boundaries, imposition of curfews, etc. The decrease of foreigner customers has certainly an impact on the loss of profit of many entrepreneurs. Czech state, however, is not liable to the measures adopted by other states. Many measures were adopted by Czech and foreigner companies from their own initiative without being compelled by the crisis measures of the state to close a business or restrict production or sale. It is also necessary to note the obligation of prevention imposed by the Civil Code, i.e. to conduct so as to avoid damage to health and property of third parties. Therefore, in the course of doing business entrepreneurs must adopt measures that may have an impact on the scope of offered goods or services, in fact, the prevention necessarily results in the rising costs of hygiene matters. There is a fact that needs to be taken into account, whether an entrepreneur made use of the possibility to sell goods or services in a way other than direct sale in venues, as the ban did not apply to a shop window 
sale in certain period and a form of e-shop was a reasonable alternative in case of many entrepreneurs.

As for the burden of proof, the injured is in the position to prove the actual damage or loss of profit. Courts will probably resort to using such procedural institutes that will result in reducing the degree of evidence against practical certainty. According to the Civil Procedure Code: 'where it is not possible to exactly determine the amount of the compensation of damage, a court will determine it by considering the individual circumstances of the case fairly. Where it is possible to find out the amount only with disproportional difficulties or it is not possible to ascertain it at all, the court will determine it upon its consideration'

It may not be possible to make claims for the wages paid to employees as they are so called wasteful expenditures, which are not reimbursed

If the injured person inflicted the damage on himself or herself, the claim for compensation of damages is not established. Further, if an entrepreneur neglected to adopt such measures that would result in mitigating the effects of crisis measure, moreover, if he or she failed to apply for compensations paid by the state to mitigate the effects of crisis measures, or contractually excluded himself or herself from protection provided by the Civil Code within contractual law. However, it will not be possible to account for public benefit from the adopted measures. It would exclude the state's liability as such

A claim for compensation will not be established in the cases when the adopted measures aim at something different than purely reacting to an occurred crisis situation. If, for instance, the emerged situation results in creating stricter legislation for the protection of health with consequences after the end of epidemic, there is not a casual relation of such measure and occurred damage.

A claim must be asserted in subjective, in fact objective time-limit, otherwise, it becomes extinguished, with regards to the body of authority that has issued the measure. The petition would be against the state or region

\subsubsection{Liability for damage according to Act referring to the state's liability for damage incurred upon during the enforcement of public authority by decision or maladministration}

The claim for compensation of damage is formulated in this legislation (section 7 and 8) as follows: 'the right to compensation of damage incurred by unlawful decision belong to the parties to procedure in which there was issued a decision incurring damage upon them. The claim for compensation incurred by unlawful decision can, unless provided otherwise, be asserted only then where the final and conclusive decision was reversed for unlawfulness or modified by a competent body. The decision of this body is binding for a court involved in deciding on compensation of damage. Where the extraordinary cases are not concerned, the claim for damage incurred by unlawful decision can only be asserted, when the injured person has used all procedural measures within time-limits determined by the state, provided by the state for the injured person to protect his or her rights; such a measure is a regular remedial measure, extraordinary relief, except a proposition to a new trial, and other procedural measure to protect law with the enforcement of which it is connected a commencement of civil proceedings, administrative proceedings or legal proceedings, or a motion to discontinue an enforcement of the judgement of the court.'

From our perspective of an entrepreneur affected by the ban on or restriction of sale we move our focus of attention to a measure of general nature issued by the Ministry of Health 
according to Act 258/2000 Sb. [14], Regarding the protection of public health (section 69, paragraph i). However, it is necessary to acknowledge that even the measures adopted by the Ministry of Health are crisis measures in the sense of the Crisis Act, although they are not issued with a reference to this law.

The measures of general nature are defined by the Rules of Administrative Procedure (Act No. 500/2004 Sb. [15], as amended) in section 171. It is an administrative act issued according to special legislation that is not a legal regulation or an administrative decision (it aims at a larger range of persons concerned, but it is not generally binding for everyone). The remedial measure for such a provision is an 'administrative action' according to section 101a and the following Act No. 150/2002 Sb. [16], the Rules of Administrative Procedure, as amended. The motion to terminate the measure is put forward to a regional court. The person who claims that his or her rights have been violated by the measures of general nature issued by administrative body is entitled to put forward a motion to terminate the measures of general nature or its parts. If he or she is entitled in compliance with the law in a case, in which the measure of general nature was enforced, bring an administrative action or other motion within administrative judiciary, he or she can suggest terminating the measure of general nature only concurrently with such a motion. The motion can be put forward within one year period starting on the day when the measure challenged by the motion came into effect.

Therefore, it will be essential, who can assert a claim for the compensation of damage according to Act No. 82/1998 Sb. [12], regarding the measures of general nature, and whether such a measure can be a ground for asserting a claim for the compensation of damage, when the text of the law uses the term 'decision', but a measure of general nature is not a decision.

The decision of Municipal Court in Prague, which decided on the motion to terminate the measure of the Ministry of Health banning or restricting retail sale, can be an appropriate initial guideline. The motion was satisfied on the merits by a judgement, which is not final and conclusive, on 23.04 .2020 c.j. 14 A 41/2020. Is it possible to conclude that the terminated measures of the Ministry of Health give rise to a claim for the compensation of damage according to the above mentioned law?

The municipal Court in Prague allowed the unlawfulness of these measures. Let us quote the most relevant reasons in short:

Crisis Act is a special regulation in relation to Act Regarding the protection of public health, with regard to the state of emergency, only the government, not the Ministry of Health, was authorised to restrict the fundamental rights and freedoms to such a massive extent.

Failure to adopt the measure by the government according to the Crisis Act, but adopting it by the Ministry of Health according to the Act Regarding public health is considered by the court as a violation of constitutional guarantees of the division of power. By adopting the measures by the Ministry of Health according to the Act Regarding the protection of public health, the control by the Chamber of Deputies was eliminated. The Ministry violated its subject-matter competence.

Considering the possibility to assert a claim for the compensation of damage caused by the terminated measure of general nature, I tend to accept the conclusion that legislation allows such interpretation [17]. Also note the reasoning of the governmental bill No. 160/2006 Sb. [18], or the judgement of the Supreme Court (NS) on 08.08.2017, sp. Zn. 30 Cdo 3292/2015, NS judgement on 27.10.2015, sp. zn. 25 Cdo 3444/2013, NS judgement on 08.08.2017, sp. zn. 30 Cdo 3292/2015; NS judgement on 11.09. 2018, sp. zn. 30 Cdo 3079/2016; NS judgement on 11.09.2019, sp. zn. 30 Cdo 1642/2018 [19-22]. 
Whereas the measures in question are not issued on the basis of a previous motion, then it is not conditional that the person concerned makes objections according to the Rules of Administrative Procedure. The ground giving rise to the claim is proposing a successful motion to terminate the measure of general nature of the Ministry of Health.

As for the right to sue (locus standi) and justiciability, it is conclusively presumed that 'in this situation, when it is not possible to ground the definition of the injured person by an unlawful decision on the position of the party to the proceedings, every person who suffered damage caused by this decision is entitled to sue' [23]. Such a person will be the one whose motion caused the termination of the measure, and probably all the others suffering from this terminated measure (the entrepreneurs concerned) with regard to specific causes, as these persons cannot make motions to terminate a measure that has already been terminated.

Let us summarise the prerequisites giving rise to a claim according to Act No. 82/1998 Sb. [12]: - it must be a decision (a measure of general nature), - it must be terminated for unlawfulness, - it must be final and conclusive or enforceable before it is declared final and conclusive, - an infliction of harm, - a casual interrelation between making unlawful decision and inflicting harm, - exhausting administrative remedies, - right to sue (locus standi) and justiciability. If the government substitute the terminated measure with a resolution identical in content issued according to the Crisis Act, then we may conclude that the claim for the compensation of damage is established only for the period, when the ban was based on the measure of the Ministry.

Considering the fact that the measures of the Ministry are based on the existence of the state of emergency, we suppose that the claims may be based on the Crisis Act as well. Then, the conditions according to the Act No. 82/1998 Sb. [12] would not be met.

There are relevant objections to an automatic conclusion that the termination of the measure of general nature gives grounds for a claim for the compensation of damage according to Act No. 82/1998 Sb. [12]. It is argued that there needs to be a decision (individual act) issued on the grounds of the tackled extraordinary measures of the Ministry of Health, only that can subsequently be terminated on the grounds of unlawfulness (e.g. decision on administrative delict). According to the judgement of the Supreme Court on 26.08.2014, sp. Zn. 30 Cdo 2767/2013 [24] 'the fact that a person believes to have suffered damage or harm as a consequence of violating the rights of another on the grounds of a previous unlawful decision, does not constitute the person to be naturally a party to the proceedings and the person does not obtain a right to sue (locus standi) according to Act No.82/1998 sb.)' [12].

\section{Discussion and conclusion}

Within discussion, the authors highlight two, in their opinion, key issues.

First, what legal regime will be imposed upon the cases, when a person suffered harm by a legal act of the state, however, it is not possible to apply Act No. 82/1998 Sb. [12], or any other particular piece of legislation. In general, the legal regulation of the compensation of harm according to the Civil Code, unfortunately, there is lack of sufficient specifying judicial decisions. The Supreme Court allowed in its judgement on 31.07.2019, c.j. 30 Cdo 2301/2017-144 [25], in compliance with the Charter of Fundamental Rights and Freedoms, that: 'if Act No. 82/1998 Sb. does not establish liability to damage during the performance of public authority (and its reimbursement), as it was in the reviewed case, it does not mean that the liable entities are without liability, but 'only' that their liability is not governed by 
Act No. 82/ 1998 Sb. [12], but it is governed by general provisions for 'the compensation of harm'.

The second issue relates to the problem indicated in the introduction, which bodies of public authority decide on constitutionality and legality of crisis measures. The way of administrative judiciary has already been indicated. In the case of exhausting of all remedial measures including an appeal before the Court of Appeal, the Constitutional Court may decide the case.

As far as the Constitutional Court is concerned (resolution on 22.04.2020, sp. zn. Pl. US 8/20 [26]), it clearly referred to the resolutions of the government, that : 'the declaration of the state of emergency is primarily an act of the application of constitutional law; it represents an 'act of governing' that has a normative effect, it is not principally a subject of the control of the Constitutional Court and it is 'reviewable' by primarily democratically elected political (non-judiciary) body that is the Chamber of Deputies. The act of declaring the state of emergency could be terminated by the Constitutional Court, if it were in conflict with the fundamental principles of a democratic rule of law. The government determined, in the resolution on the declaration of the state of emergency, the restricted rights by referring to section 5 paragraph a) to e) and section 6, the Crisis Act and to a further specifying resolution of the government. Although, such implicit determination is general and vague, it cannot be regarded as an excessive violation or misuse of constitutional law. It cannot be concluded from the given defect of form that the decision to declare the state of emergency is invalid, as excessively strict assessment of formal elements would completely omit the seriousness and extraordinary quality of the situation leading to the declaration of the state of emergency'.

Upon analysing the above given documents, we may conclude that the entrepreneurs concerned need to assemble all the relevant sources for asserting possible claims for the compensation of damage from the state. In the first phase it should be considered to what extent a particular entrepreneur prevented the infringement of harm, whether all appropriate measures were adopted to prevent of minimalize it.

With respect to the missing judicial decisions on the specifics of measures in the period of this state of emergency, every entrepreneur must consider a regime for asserting claims, whether by the way of the Crisis Act or Act No. 82/1998 Sb. [12]. Cautiously, both ways are recommended concurrently.

Asserting a claim must be duly and timely to the statutory body specified in legislation. The claim must be determined as accurately as possible and it must be attached with evidence in writing or other form. In this sense, it is necessary to have a sufficient record of every internal decision and act of the entrepreneur (instructions to employees, closure of business, etc.), register all communication with business partners and customers, contracts and amendments of contracts reacting to the crisis situation. Even photography or audio recordings proving the conduct of the entrepreneur are recommended. It is always necessary to distinguish which procedures the entrepreneur adopted for prevention and which, on the contrary, were adopted for the purpose of mitigating the effects of state crisis measures.

As for the calculation of real damage and loss of profit, the claims must be certified with particular documentation - contracts, the amendments of contracts, bank statements, the records of meetings, withdrawals from contracts, annual balance-sheet reports and further accounting documents, ideally an expert's report to prove a loss of profit.

A particular application (notice, assertion) must be specific and comprehensible. 


\section{Acknowledgment}

The paper was created within the project of the Internal Grant Competition 2020 of the Institute of Technology and Business in České Budějovice Nr. 8110-003.

\section{References}

1. Z. Firano, F. A. Fatine, The COVID-19: macroeconomics scenarii and role of containment in Marocco. One Health. 10 (2020)

2. N. Donthu, A. Gustafsson, Effect of COVID-19 on business and research. Journal of Business Research. 117, pp. 284-289 (2020)

3. D. D. Farias, F. F. de Araujo, Will COVID-19 affect food supply in distribution centers of Brazilian regions affected by the pandemic? Trends in Food Science \& Technology. 103, pp. 361-366 (2020)

4. A. A. Malinovsky, D. M. Osina, E. N. Trikoz, State support for the Russian economy affected by covid-19 consequences. Lecture Notes in Network and Systems. 139, pp. 283-287 (2020)

5. S. Varelas, N. Apostolopoulos, The Implementation of Strategic Management in Greek Hospitality Businesses in Times of Crisis. Sustainability. 12(17) (2020)

6. N. Caruso, S. Mela, E. Pede, A resilient response to the social-economic implications of coronavirus. The case of Snodi Solidali in Turin. Urban Research \& Practice. (2020)

7. T. A. Perkins, G. Espana, Optimal Control of the COVID-19 Pandemic with Nonpharmaceutical Interventions. Bulletin of Mathematical Biology. 82(9) (2020)

8. R. Aldaco, D. Hoehn, J. Laso, M. Margallo, J. Ruiz-Salmón, J. Cristobal, R. Kahhat, P. Villanueva-Rey, A. Bala, L. Batlle-Bayer, P. Fullana-i-Palmer, A. Irabien, I. VasquezRowe, Food waste management during the COVID-19 outbreak: a holistic climate, economic and nutritional approach. Science of the Total Environment. 742(10) (2020)

9. M. Mehrl, P. W. Thurner, The Effect of the Covid-19 Pandemic on Global Armed Conflict: Early Evidence. Political Studies Review. (2020)

10. X. Neumeyer, W. S. Ashton, N. Dentchev, Addressing resource and waste management challenges imposed by COVID-19: An entrepreneurship perspective. Resources, Conservation and Recycling. 162 (2020)

11. ČESKO, 2000. Zákon č. 240 ze dne 9 . srpna 2000 zákon o krizovém řízení a o změně některých zákonů (krizový zákon). In: Sbírka zákonů České republiky. Částka 73, s. 3475-3487. ISSN 1211-1244.

12. ČESKO, 1998. Zákon č. 82 ze dne 15. dubna 1998 zákon o odpovědnosti za škodu způsobenou při výkonu veřejné moci rozhodnutím nebo nesprávným úředním postupem a o změně zákona České národní rady č. 358/1992 Sb., o notářích a jejich činnosti (notářský řád). In: Sbírka zákonů České republiky. Částka 31, s. 5058-5063. ISSN 1211-1244. 
13. ČESKO, 1998. Ústavní zákon č. 110 ze dne 29. května 1998 Ústavní zákon o bezpečnosti České republiky. In: Sbírka zákonů České republiky. Částka 39, s. 53865387. ISSN 1211-1244.

14. ČESKO, 2000. Zákon č. 258 ze dne 11. srpna 2000 zákon o ochraně veřejného zdraví a o změně některých souvisejících zákonů. In: Sbírka zákonů České republiky. Částka 74, s. 3622-3662. ISSN 1211-1244.

15. ČESKO, 2004. Zákon č. 500 ze dne 24. června 2004 zákon správní rád. In: Sbírka zákonů České republiky. Částka 174, s. 9782-9844. ISSN 1211-1244.

16. ČESKO, 2002. Zákon č. 150 ze dne 21. března 2002 zákon soudní řád správní. In: Sbírka zákonů České republiky. Částka 61, s. 3306-3330. ISSN 1211-1244.

17. F. Korbel, In: F. Ištvánek, P. Simon, F. Korbel, Zákon o odpovědnosti za škodu způsobenou při výkonu veřejné moci rozhodnutím nebo nesprávným úředním postupem: Komentáŕ. Praha: Wolters Kluwer. Komentáře (Wolters Kluwer ČR) (2017)

18. ČESKO, 2006. Zákon č. 160 ze dne 27. dubna 2006 zákon, kterým se mění zákon č. 82/1998 Sb., o odpovědnosti za škodu způsobenou při výkonu veřejné moci rozhodnutím nebo nesprávným úředním postupem a o změně zákona České národní rady č. 358/1992 Sb., o notárích a jejich činnosti (notářský řád), ve znění pozdějších předpisů, zákon č. 201/2002 Sb., o Úřadu pro zastupování státu ve věcech majetkových, ve znění pozdějších předpisů, a zákon č. 40/1964 Sb., občanský zákoník, ve znění pozdějších předpisů. In: Sbírka zákonů České republiky. Částka 55, s. 1950- 1952. ISSN 1211-1244.

19. Rozsudek NS ze dne 8. 8. 2017, sp. zn. 30 Cdo 3292/2015.

20. Rozsudek NS ze dne 27. 10. 2015, sp. zn. 25 Cdo 3444/2013.

21. Rozsudek NS ze dne 11. 9. 2018, sp. zn. 30 Cdo 3079/2016.

22. Rozsudek NS ze dne 11. 9. 2019, sp. zn. 30 Cdo 1642/2018.

23. P. Vojtek, Odpovědnost za škodu při výkonu veřejné moci: Komentář, 3. vydání, C. H. Beck, Praha (2012).

24. Rozhodnutí NS ze dne 26. 8. 2014, sp. zn. 30 Cdo 2767/2013.

25. Rozsudek NS ze dne 31. 7. 2019, č. j. 30 Cdo 2301/2017.

26. Usnesení Ústavního soudu sp. zn. Pl. ÚS 8/20 ze dne 22. 4. 2020. 